Heidi SALMi

\title{
Turun murre Gustaf Renvallin kieliopissa Finsk Språklära, Enligt den rena Vest-Finska, i Bokspråk vanliga Dialecten (1840)
}

\begin{abstract}
"Derigenom är i en del Städer och månge Landsorter det öfliga Språket så råbråkadt, att det utgör hvarken Svenska eller Finska, utan är en regellös sammangyttring af dem begge, ett mischmasch, som klarligen utvisar, huru eländigt ett spårk kan blifva, då det utan urskiljning sammansättes af tvenne särskilta olikartade ingredienser, vare sig af tvenne särskilta språk, eller af tvenne skärskilta språkdialekter sammanblandade. Man besöke ett Finska talande qvinnosällskap t. ex. i Åbo. Hvilken barbarisk galimathias till samtalsspråk! t. ex. onk syster ollu visitin pääl: tul helsaman minun päällen: se on farlit seilata tormiss yli haawin o. d. m. - Väl har denna grad af förbistring i Finlands språk ännu icke hunnit till alla Städer: men får detta barnsligt löjliga och fåfänga jäktande efter utländsk grannlåt både i tal och seder obehindradt fortgå på sätt lust och böjelse innom en del af Nationen nu visar sig; så utbreder sig väl denna Svensk-Finska med stora steg, och kanske efter ett århundrade veta Finlands från sitt modersmål afvända barn icke mera, hurudant detta af deras redbara förfäder talades." (Renvall 1840, II-III.)
\end{abstract}

\section{Johdanto}

Suomen kirjakieli syntyi 1500-luvulla. Se ei perustu mihinkään yksittäiseen murteeseen, mutta lounaissuomalaisesta murteesta ja erityisesti Turun murteesta tuli Agricolan myötä kirjakielen pohja. Agricola käytti kuitenkin myös muita murteita kirjoittaessaan suomea. Kirjakielen lounainen murrepohja lujittui 1500-luvun lopulla ja 1600-luvun alussa. Vuoden 1642 Biblian myötä kielen yleiskuva selkeni, kun raamatunkäännöskomitea puhdisti Agricolan raamatunsuomennososia vieraiden kielten vaikutuksesta. Komitean tavoitteena oli kirjoittaa kieltä, jota ymmärrettäisiin joka puolella suomea, ja Bibliaan tuli piirteitä myös itäisistä murteista. Monet kirjoittajat noudattivat Raamatun kirjakieleen 
vakiinnuttamaa lounaissuomalais-satakuntalaista pohjaa vielä 1700-luvulla, mutta siihen tuli vähitellen vaikutteita myös Hämeestä ja Pohjanmaalta. Koko vanhan suomen kauden ajan savolais- ja kaakkoismurteet olivat muita murteita syrjäisemmässä asemassa. (Häkkinen 1994, 445-446; Kolehmainen 2014, 52-56.)

180o-luvun alkupuolella itämurteiden arvostus nousi kansanrunouden ja Kalevalan ansiosta, ja tuolloin alettiin tietoisesti taistella länsimurteiden ylivaltaa vastaan. Itämurteiden nousuun vaikutti myös se, että vanha kirjakieli oli vähitellen etääntynyt puhutusta kansankielestä. Silloinen kirjakieli ei tarjonnut myöskään valmiita ilmaisukeinoja, kun alettiin kirjoittaa suomeksi tieteistä, taiteista ja yhteiskunnallisista asioista. Lounaismurteiden alueen asema Suomen keskipisteenä muuttui, kun Helsingistä tuli maan pääkaupunki ja yliopisto muutti Helsinkiin. Lisäksi länsimurteissa oli paljon ruotsin kielen tuomia vieraita piirteitä, jotka todistivat tuona aikana vallinneen käsityksen mukaan kielen turmeltuneisuudesta. Kielentutkijat halusivat etsiä kielen alkuperäistä muotoa, jonka ajateltiin voivan olla koko kansaa yhdistävä tekijä. (Häkkinen 1994, 447-449; ks. myös Kolehmainen 2014, 56-58.) Tämän ns. murteiden taistelun lopputulos oli kompromissi, jossa länsimurteisiin perustunut kirjakieli säilyi mutta sai runsaasti erilaisia piirteitä itämurteista.

Länsimurteiden puolustajan Kustaa Renvallin mukaan eri murteiden käyttö kirjakielessä teki kielestä "amalgaamaa", jossa eri murteiden muodot "murhasivat toisiaan" eivätkä tehneet kieltä helpommin ymmärrettäväksi kenellekään. Kirjakielen pohjaksi tuli hänen mukaansa valita jokin murre, jota voitaisiin parannella muiden murteiden aineksilla. (Lauerma 2004, 160.) Renvall perusti oman vuonna 1840 ilmestyneen kielioppinsa puhtaaseen länsimurteeseen, jota puhutaan pohjoisessa Satakunnassa ja Hämeenlinnan ja eteläisen Pohjanmaan välillä. Se on Renvallin mukaan kaikkein "kultivoitunein" kielimuoto ja se on ollut jo vanhastaan kirjakielen käytössä. Renvall perustelee kielimuodon käyttöä myös sillä, että se on tuttu kautta Suomen ja vieraat kielet ovat vaikuttaneet siihen kaikkein vähiten. Se on lähimpänä kielen alkuperäistä luonnetta ja muotoa. Renvall kirjoittaa: "Den [Vest-Finska dialect] förtjenar allså framför andra Finska dialecter den mesta uppmärksamhet för sin högre bildning och odling, sin utredda regelbundna Grammatik och den vidsträcktare bekantskap, som den under tidernas längd sig tillvunnit." (Renvall $1840,7$. ) Sen sijaan Turun murretta Renvall pitää "barbaarisena" ja halveksuu murteen puhujien käyttämiä vierasperäisiä kielenpiirteitä.

Tarkastelen tässä artikkelissa, mitkä ovat ne piirteet, jotka Renvall esittää kieliopissaan turunmurteisiksi. Renvallin kielioppi sisältää suomen kielen muoto-opin. Kielioppi alkaa esipuheella, josta artikkelin alussa oleva sitaatti on poimittu. Kieliopin johdannossa Renvall käsittelee suomen kielen murteita ja kirjakieltä. Varsinainen muoto-oppi sisältää kolme osaa: nominit, verbit ja partikkelit. Turun murretta Renvall käsittelee kieliopissaan tyypillisesti alaotsikoiden "Anmärkningar om Dialekt-olikheter" ja "Anmärkningar" alla, mutta toisinaan myös varsinaisessa muoto-opissa, kuten possessiivisuffiksien kohdalla (ks. Renvall 1840, 79).

Kuten yllä olevasta sitaatistakin voi päätellä, Renvall käsittelee Turun murretta kieliopissaan poleemisesti. Piirteet, jotka Renvall katsoo turunmurteisiksi, eivät kuitenkaan 
ole pelkästään Turun murteelle ominaisia, vaan ne ovat käytössä huomattavasti laajemmin suomen murteissa. Mielenkiinnon kohteena artikkelissa on myös se, kuinka laajaalaisia murrepiirteitä turunmurteisiksi esitetyt piirteet ovat.

Artikkeli antaa uutta tietoa 180o-luvun kielioppien kirjoittamisesta ja erityisesti Renvallin kieliopista. Se avaa uuden näkökulman Renvallin kieliopin tutkimukseen tarkastelemalla kielioppia murteentutkimuksen näkökulmasta. Tutkimus antaa kuvan siitä, millaisia piirteitä Turun murteessa $1800-$ luvulla Renvallin mukaan oli.

Esittelen tutkimuksen taustaksi ensin suomen kielen vanhimmat kieliopit, näkemyksen suomen kielen murteista sekä Turun murretta erityisesti historiallisesta näkökulmasta. Käsittelen Renvallin turunmurteisiksi esittämät piirteet kolmessa ryhmässä: 1) vokaaleja koskevat piirteet, 2) konsonantteja koskevat piirteet ja 3) yksittäisiä sanoja koskevat piirteet.

\section{Suomen kielen vanhimmat kieliopit}

Vanhimmat suomen kieliopit ovat 1600-luvulta. Esittelen tutkimuksen taustaksi lyhyesti Renvallin kielioppia edeltäneet kieliopit, sillä kieliopit muodostavat suomen kielen kuvauksen jatkumon. Kielioppien kirjoittajat ovat tunteneet aiemmat kieliopit ja käyttäneet niitä oman kuvauksensa pohjana ja myös poikenneet niistä tietoisesti. Kielioppien kehitystä ovat ohjanneet käytännön päämäärät. Aluksi kielioppeja tarvittiin erityisesti suomen opettamiseen muunkielisille.

Vanhin säilynyt kielioppi on piispa Eskil Petraeuksen Linguae Finnicae Brevis Institutio (1649). Se oli tarkoitettu ulkomaalaisille, lähinnä ruotsalaisille, joiden piti oppia suomea. Vielä 1600-luvulla ajateltiin, että latina ilmensi logiikan lainalaisuuksia ja soveltui kaikkien kielten kuvauksen rungoksi. Petraeuksen kielioppi pyrkikin sovittamaan suomen kielen latinan kieliopin sääntöihin. Vuonna 1689 ilmestyi Matias Martiniuksen Hodegus Finnicus eller Finsk Wägwijsare, jota voidaan pitää Petraeuksen kieliopin mukaelmana (Vihonen 1978, 32-34; Häkkinen 1994, 104-106; ks. myös Laine 1997, 207-209). ${ }^{1}$

Vuonna 1733 ilmestyi Bartholdus Vhaelin Grammatica Fennica, joka sisältää äänneja muoto-opin. 1700-luvulla latinan kieliopin universaaliutta alettiin epäillä, ja Vhaelin kieliopissa pyritään kuvaamaan suomen kieltä sen omista lähtökohdista käsin. Siinä kiinnitetään huomiota myös murteiden eroihin. (Häkkinen 1994, 106; Lehikoinen-Kiuru 2009, 28, 40-41.)

1 1500-luvun lopulta tai 1600-luvulta on myös suomen kielioppi Rudimenta linguae finnicae breviter delineata, joka löydettiin vuonna 2008. Rudimentan kieliopillinen kuvaus lähtee latinan kieliopin pohjalta, mutta Rudimenta poikkeaa paljon Petraeuksen ja Martiniuksen kieliopeista, joten sitä ei voi pitää niiden tiivistelmänä. (Palkki-Lauerma-Kuutti 2009, 11-14.) Lisäksi kirjallisuudessa on säilynyt tietoja vuosina 1634-1652 Naantalin kappalaisena toimineen Henricus Crugeruksen laatimasta suomen kieliopin käsikirjoituksesta. Käsikirjoitusta ei ole enää olemassa, mutta eräät tanskalaiset ovat lainanneet sitä 1680-luvulla ilmestyneissä teoksissaan. (Mark 1949; Vihonen 1978, 28-29; Häkkinen 1994, 104-105.) 
180o-luvulla ennen Renvallin kielioppia ilmestyi viisi kielioppia, ensimmäisenä Johan Stråhlmanin (kieliopissa Strahlmann) saksankielinen Finnische Sprachlehre für Finnen und Nicht-Finnen (1816). Ensimmäinen ruotsinkielinen suomen kielioppi on Jaakko Juteinin (Judén) Försök till utredande af Finska Språkets Grammatik (1818). Juteini ei pyri kieliopissaan tasapuoliseen esitykseen suomen kielestä, vaan hän keskittyy niihin asioihin, joita aiemmissa tutkimuksissa ei ollut tarkasteltu hänen mielestään riittävän laajasti. (Häkkinen 1994, 106-107.)

Itämurteiset vaikutteet tulivat kielioppeihin Reinhold von Beckerin Finsk Grammatikin (1824) myötä. Se on aiempia kielioppeja huomattavasti laajempi, ja se käsittää oikeinkirjoitusopin, muoto-opin ja laajan lauseopin. Von Beckerin kielioppiin verrattuna M. V. Wikströmin koulukieliopiksi tarkoitettu Försök till en Finsk grammatika (1832) ja G. Okulofin venäjänkielinen kielioppi Grammatika Finskago Jazika (1836) ovat vaatimattomia. (Häkkinen 1994, 106-107.)

1840-luku oli kielioppien kulta-aikaa. Silloin alettiin kohentaa suomen kielen yhteiskunnallista asemaa ja kieltä haluttiin kehittää kieliopillisen kuvauksen pohjalta. (Häkkinen 1994, 108.) Vuonna 1840 ilmestyi Kustaa (Gustaf) Renvallin muoto-opin sisältävä Finsk Språklära. Engligt den rena Vest-Finska, i Bokspråk. Halikkolainen Renvall kirjoitti Turussa ylioppilaaksi, hänet vihittiin papiksi vuonna 1806, ja hänestä tuli maisteri vuonna 1810. Renvall tutki suomen kielen ääntämistä ja oikeinkirjoitusta sekä nominien taivutusta, ja hän julkaisi vuonna 1826 sanakirjan Suomalainen Sana-Kirja, Lexicon Linguae Finnicae I-II. Hän toimi Turun Akatemiassa suomen kielen dosenttina sekä vuodesta 1819 alkaen Uskelan ja myöhemmin Ulvilan kirkkoherrana. (Heikinheimo 1955, 621622.) Renvallin oma murretausta oli siis vahvasti lounaismurteinen, ja hän tunsi Turussa asuneena Turun murretta.

Kuten Renvallin kieliopin nimestäkin näkyy, se on länsimurteita puoltava teos. Renvall halusi pitää Ruotsin vallan aikana syntyneen kirjallisen perinteen kirjakielen pohjana ja poistaa kielestä muukalaisuudet, jotka olivat tulleet kieleen lähinnä ruotsin vaikutuksesta (Häkkinen 1994, 108). Renvall kertoo kieliopin esipuheessa sen olleen käsikirjoituksena valmiina jo vuosina 1815-1819. Jos kielioppi olisi julkaistu tuolloin, se olisi ilmestynyt ennen von Beckerin kielioppia. Renvallin kielioppi kuuluukin monessa suhteessa, esimerkiksi nominien taivutusopin kannalta, esi-beckeriläiseen aikaan. (Wiik 1990, 100.)

\section{Suomen murteet nykykäsityksen ja Renvallin mukaan}

Suomen murteet voidaan nykykäsityksen ${ }^{2}$ mukaan jakaa länsi- ja itämurteisiin. Länsimurteisiin kuuluvat lounaismurteet, lounaiset välimurteet, hämäläismurteet, eteläpohjalaismurteet, keski- ja pohjoispohjalaismurteet ja peräpohjalaismurteet. Itämurteita ovat savolaismurteet ja kaakkoismurteet. (Ks. esim. Rapola 1969; SMS 1, XX-XXI; Wiik 2006, 27.)

2 Nykykäsityksellä viittaan 1900-luvun jälkipuoliskolla ja 200o-luvulla tehtyyn murretutkimukseen. 
Myös Renvall jakaa suomen murteet länsi- ja itämurteisiin. Hän kuvaa murteita hyvin värittyneesti. Länsimurteita puhuvat suomalaiset, joihin kuuluvat Renvallin ajan Varsinais-Suomen (Turun alueen) ja Satakunnan asukkaat, hämäläiset ja Pohjanmaalla asuvat kainulaiset. Kaikissa läntisissä murteissa on Renvallin mukaan samanlaisia piirteitä ja samanlainen kielioppi. Turun alueen rannikkosuomi (Turun murre) on kuitenkin muuttunut vähitellen "vahvan loppuheittoiseksi" tai "rumasti typistetyksi". Siitä on tullut "ruotsalaistettu ja puolivirolaistettu kielimuoto", mikä johtuu murteen läheisestä yhteydestä ruotsiin ja viroon. Renvallin mukaan jo kahden kolmen peninkulman päässä rannikolta myös Turun alueen puhe muuttuu täydellisemmäksi ja puhtaammaksi ja lähenee vähitellen Satakunnan murteita. Myös hämäläismurteiden itäiset alueet ovat saaneet joitain hämäläismurteisista piirteistä poikkeavia ja niitä huonompia piirteitä savolaismurteista. Jopa pohjoiset pohjalaismurteet ovat sekoittuneet savolaismurteiden kanssa. (Renvall $1840,2-4$.)

Länsimurre on pysynyt Renvallin mukaan puhtaimpana ja sekoittumattomimpana pohjoisessa Satakunnassa ja alueella Hämeenlinnasta pohjoiseen ja luoteeseen, eteläiseen Pohjanmaahan saakka. Näillä alueilla ruotsin ja venäjän vaikutus ei ole häirinnyt kielen kehitystä, vaan kieli on saanut kehittyä puhtaimmin oman, kansallisen ja itsenäisen luonteensa mukaan. Länsimurre on voinut muodostaa näillä alueilla yhtenäisen rakenteen ja säännöllisen kieliopin. Lisäksi länsimurre oli kauan melkein yksinään kirkon ja kirjoituksen kieli, minkä ansiosta kielimuoto on täydellistynyt edelleen ja tullut tunnetuksi kaikkialla Suomessa. (Renvall 1840, 4.)

Renvall toteaa, että itämurteita puhuvat savolaiset ja karjalaiset, jotka ovat muuttaneet Suomeen länsimurteiden puhujia myöhemmin. Itämurteilla on keskenään monia samanlaisia piirteitä, mutta Savon murteen ja Karjalan murteen välillä on myös eroja. Savolaiset sanovat esimerkiksi minä ja karjalaiset mie, miun. Itämurteita puhutaan Itä-Suomessa ja Kajaanin alueella. Puhtaimmillaan ne ovat Kuopion seudulla ja Kuopiosta itään. Hämäläismurteet ja pohjoisen suunnalla pohjalaismurteet ovat vaikuttaneet itämurteisiin, ja lisäksi niissä on venäjän kielen vaikutusta. Itämurteet ovat näiden kielimuotojen vaikutuksesta epäsäännöllisempiä kuin länsimurteet, eivätkä ne ole kehittyneet itsenäisesti. Koska itämurteita ei ole koskaan käytetty kirjakielessä eikä niiden kieliopillisia piirteitä ole tutkittu tarkemmin, ne ovat tuntemattomia länsisuomalaisille. (Renvall 1840, 5.)

\section{Turun murre}

Turun murteen alku voidaan sijoittaa noin vuoden 1000 eaa. paikkeille, jolloin Turusta tuli yhä tärkeämpi kauppapaikka, jonne muutti väestöä eri suunnilta. Alueen murre oli keskiajalla ja sen jälkeen neljältä suunnalta - luode, koillinen, itä ja etelä - tulleiden vaikutteiden sekoittumisalue. Lisäksi Turkuun tuli ulkomaalaisia, sillä Suomi oli osa Ruotsin valtakuntaa ja Turku lähellä Itämerta ja hansakauppaa. 160o-luvun Turussa liikkuikin kolmea kieltä puhuvaa väkeä: suomalaisia, ruotsalaisia ja saksalaisia. Turun murre alkoi edustaa lounaissuomalaisen murteen kaupunkilaismurretta, johon vieraat kielet 
vaikuttivat enemmän kuin ympäristön maaseudun murteisiin. Siinä oli enemmän "hienoja vieraskielisiä piirteitä” kuin ympäristöalueiden murteissa. (Wiik 1998, 10, 13-15.)

Turku oli 1200-luvulta alkaen Suomen hallinnollinen ja hengellinen keskus sekä keskeinen opiskelukaupunki. Turussa oli katedraalikoulu, ja vuonna 1640 perustettiin Suomen Akatemia, joka oli tuohon aikaan ainoa Suomen yliopisto. (Ranta 1975, 829-830.) Turun murteeseen on vaikuttanut myös se, että Turussa kehittyi jo keskiajalla jonkinlaista suomen yleiskieltä papiston ja virkamiehistön kieleksi (Rapola 1969, 36-37). Näin ollen murteeseen omaksutut yleiskieliset piirteet voivat olla vanhaa perua (Grönholm 1988, 5-6). Turun prestiisiaseman vuoksi lounaissuomalaisuuksia on levinnyt koulutetun väen kautta muihin suomen murteisiin.

Vanha Turun murre on lähempänä lounaismurteita kuin lounaisia siirtymämurteita, jotka sijaitsevat lounais- ja hämäläismurteiden välissä ja joissa on niin lounais- kuin hämäläismurteisia piirteitä. Turku sijaitsee suomen murrekartalla kohdassa, jossa lounaismurteen pohjois- ja itäryhmät ja siirtymämurteisiin kuuluva Turun ylämaan murre kohtaavat toisensa, ja myös hämäläismurteet ovat vaikuttaneet Turun murteeseen. Turun murre onkin liian hämäläisvoittoinen ollakseen puhdas lounaismurre, mutta liian lounaissuomalainen ollakseen puhdas lounainen siirtymämurre. (Grönholm 1988, 5-6; Wiik 1998, 18; Wiik 2006, 27.) Lauri Kettunen $(1930,16)$ katsoo Turun murteen olevan lounaismurteiden ja hämäläismurteiden välisiä sekamurteita. Sekamurteille on tyypillistä se, että useat eri ympäristömurteiden edustukset voivat varioida niissä (Palander 1996, 14). Heikki Ojansuu puolestaan jättää epäyhtenäisen Turun murteen kokonaan Suomen lounaismurteiden äännehistorian tutkimuksen ulkopuolelle (1901; 1903).

Kaikenlainen kielellinen vaihtelu on hyvin tyypillistä kaupunkikielissä (Labov 1971, 166; Saari 1980, 28). Kaupunkimurteet ovat tyypillisesti epäyhtenäisempiä kuin kansanmurteet, ja Turun murteen epäyhtenäisyyteen on vaikuttanut lisäksi Turun sijainti murrerajalla, lounaismurteiden ja hämäläismurteiden vaikutuksen alaisena (Ikola 1972, 22).

\section{Turun murrepiirteet Renvallin kieliopissa}

Käsittelen Renvallin kieliopissa Turun (ja Turun alueen) murteelle tyypillisiksi esitetyt piirteet kolmessa ryhmässä. Ensimmäisen ryhmän muodostavat vokaaleja koskevat murrepiirteet, toisen konsonantteja koskevat murrepiirteet ja kolmannen yksittäisiä sanoja koskevat murrepiirteet. Esittelen ensin kunkin piirteen ja sen levikin erityisesti Kalevi Wiikin (2006) tutkimuksen mukaan. Tämän jälkeen tarkastelen piirrettä Turun murteen näkökulmasta. Koska 1800-luvun Turun murteesta ei ole tutkimustietoa, on tyydyttävä 1900-luvun loppupuolen ja 2000-luvun Turun murteeseen, johon ilmaukseni nykyinen Turun murre viittaa. Lopuksi esitän, mitä Renvall kirjoittaa kieliopissaan kyseisestä piirteestä, ja tarkastelen, esiintyykö piirrettä vanhassa kirjasuomessa ja 180o-luvun kirjakielessä. 


\subsection{Vokaaleja koskevat murrepiirteet}

\subsubsection{Loppuheitto}

Suomen murteissa esiintyvässä sanojen loppuheitossa yksinäisvokaali katoaa sanan lopusta. Murteissa on monenlaista loppuheittoa, ja Wiik (2006) esittää loppuheitosta seuraavan ryhmittelyn:

1) lounaismurteiden foneettispohjainen loppuheitto koskee sananloppuisia vokaaleja, jotka eivät ole puolipitkiä ja jotka esiintyvät muussa ympäristössä kuin lyhyen painollisen tavun jäljessä, kuten pitk nok

2) lounaismurteiden alkusuljetun $\operatorname{tavun}^{3}$ morfologinen loppuheitto koskee tiettyjä muotoryhmiä, kuten syämät (syömättä), ist ny (istu nyt). Alkusuljettu tavu on alkuaan ollut konsonanttiloppuinen mutta on muuttunut myöhemmin loppukonsonantin kadottua vokaaliloppuiseksi, kuten talollen $>$ talolle, tulektek $>$ tulettek $>$ tulette $>$ tulet

3) länsimurteiden $i$ :n loppuheitto koskee suffiksien vokaalia tietyissä muotoryhmissä, kuten suureks, isäs (isäsi), makas

4) itämurteiden $i$ :n loppuheitto, jossa $i$ siirtyy edellään olevaan konsonanttiin liudennukseksi, kuten $k a ̈ s i>k a ̈ s^{\prime}$

5) eteläisten murteiden suffiksien $A: n$ loppuheitto, kuten talos, talol

6) epäsäännölliseltä näyttävä loppuheitto, elisio, jota tapahtuu joissakin lausefoneettisissa asemissa, esimerkiksi kun seuraava sana alkaa vokaalilla tai kun kyseessä on kaksitavuinen partikkeli, kuten että, mutta. Tämä on yhteinen useimmille suomen murteille. (Mts. 149-154.)

Osmo Nikkilän $(1994,6-7)$ mukaan vain lounaismurteissa, joissa loppuheitto on laaja-alaista, elisiolle ei ole sellaisia edellytyksiä kuin muissa murteissa. Nikkilän mukaan lounaismurteiden loppuheitto poikkeaa muista suomen murteiden loppuvokaalin katotapauksista. Se on sidoksissa sanan pituuteen. Lounaismurteiden loppuheitossa jokainen loppuvokaali on kadonnut kolmi- ja useampitavuisista sanoista sekä niistä kaksitavuisista sanoista, joiden ensi tavu on ollut pitkä.

Leena Salomaan (1979, 261-264; ks. myös Salomaa 1981) mukaan Turun puhekielen loppuheitossa esiintyvään variaatioon vaikuttavat kielenulkoiset, sosiaaliset ja kontekstilliset muuttujat sekä kielelliset muuttujat. Variaatiota selittää ennen kaikkea sanan muotoryhmä, mutta myös muut kielelliset muuttujat, kuten loppuvokaalin laatu, sanan frekvenssi ja pituus sekä vartalotyyppi, vaikuttavat variaatioon. Turun puhekielessä käytetään edelleen useita sellaisia loppuheittomuotoja, joita ei esiinny yleispuhekielessä. Salomaan mukaan Turun puhekielessä esiintyi tutkimusaikana myös loppuvokaalien palauttamista sellaisiin asemiin, joissa vokaaleja ei esiintynyt vanhastaan.

3 Termi alkusuljettu tavu Wiikin (2006). 
Myös uudempien, joskin suhteellisen suppeiden, tutkimusten mukaan loppuheitto on Turun murteelle tyypillinen piirre. Nykyisessä Turun murteessa loppuheitto on vallitseva variantti (esiintyy 74\%:ssa mahdollisista esiintymistä), kun tarkasteltavana ovat ulkopaikallissijojen, si-loppuisten sanojen, adpositioiden, adverbien ja partikkelien sekä inessiivin loppuheitto. (Käpylä 2012, 72; Turun murteen loppuheitosta ks. myös Ollilainen 2008, 74-91 ja lounaismurteiden loppuheitosta Siitonen 1979.)

Renvall käsittelee loppuheittoa sekä nominien että verbien yhteydessä. Renvallin mukaan Turun alueen rannikkosuomalaisten kielessä (ja eteläsavolaisilla) on loppuheittoa. Loppuheiton seurauksena sana loppuu usein kahteen konsonanttiin, kuten leiwäll, leiwäst, yks, kaks. Verbejä käsitellessään Renvall toteaa, että pitkät päätteet lyhenevät Turun murteessa vastaavasti kuin nominit, kuten sanom (sanomme), kiros, kirosim. Lisäksi possessiivisuffiksit ovat Turun murteessa loppuheittoisia: $-n,-s,-n s,-m,-n,-n s$, kuten leipän (leipäni), leipäs, leipäns, leipäm, leipän, leipäns. Tätä "rumaa typistämistä" esiintyy Renvallin mukaan myös vanhassa virsikirjassa ja muissa hengellisissä lauluissa. Renvall pitää loppuheittoa kielen alkuperäisen luonteen vastaisena. Suomen kielessähän esimerkiksi lisätään lainasanojen perään yleensä vokaali, jotta voidaan välttää "asiaton loppuäänne". Näin on tehty esimerkiksi sanoissa lappu (lapp) ja rukki (rock). (Renvall 1840, 20, 44, 79, 90-91.)

Renvallin loppuheitosta antamat esimerkit edustavat lounaismurteiden alkusuljetun tavun morfologista loppuheittoa, länsimurteiden $i$ :n loppuheittoa ja eteläisten murteiden suffiksien A:n loppuheittoa. Loppuheitto on tyypillinen Turun murteelle (Salomaa 1979), mutta loppuheitossa on kyse laajasti lounaismurteiden alueelle ja osittain länsimurteille tyypillisestä ilmiöstä eikä pelkästään Turun alueen rannikon kielessä esiintyvästä ilmiöstä, kuten Renvall esittää. Vanhassa kirjasuomessakin loppuheitto on hyvin tavallista 1700-luvun lopulle asti (Häkkinen 1994, 189).

\subsubsection{Painottomien vokaalien lyheneminen}

Turun murteelle ja Turun lähialueiden kielelle on tyypillistä se, ettei niissä käytetä pitkiä vokaaleja painottomissa tavuissa, vaan sanotaan esimerkiksi asuk (asuuko). Tämän murrepiirteen taustalla on ruotsin kieli, jossa ei ole painottomia pitkiä vokaaleja. Turun ruotsinkieliset ovat vanhastaan ääntäneet suomea ruotsalaisesti murtaen ja antaneet mallin myös suomalaisille. (Wiik 1998, 44-45.)

Myös Renvall (1840, 44, 90-91) kiinnittää kieliopissaan huomiota tähän vokaalien lyhenemiseen ja toteaa, että Turun alueen rannikkomurteissa lyhennetään pitkiä vokaaleja, kuten wieran, wieraks ja jopa sano (sanoo) ja kiron (kiroon). Vanhassa kirjasuomessa pitkiä vokaaleja saatettiin kirjoittaa lyhyillä vokaaleilla, mutta lyhyissä vokaaleissa on kyse lähinnä kirjoitusasusta. Vasta 1800-luvun alkupuolelta lähtien kieli-ihmisille oli selvää, että lyhyen ja pitkän vokaalin vastakohta on merkittävä tekstiin. (Ks. esim. Häkkinen 1994, 178, 181.) 


\subsubsection{Painottomien vokaaliyhtymien monoftongiutuminen}

Vokaaliyhtymät voidaan jakaa monoftongiutumisen kannalta kolmeen ryhmään: 1) eA, 2) $O A$ sekä 3) iA ja UA (Wiik 2006, 155-160). Vokaaliyhtymien kehitykseen ovat vaikuttaneet toisilleen vastakkaiset pitkävokaalistumis- ja tavunrajansäilyttämistendenssi. Pitkävokaalistuminen on toteutunut laajemmalla alueella $e A$ - ja $O A$-yhtymissä kuin $i A$ - ja $U A$-yhtymissä, ja kehitys on johtanut samassakin murteessa eri suuntiin eri vokaaliyhtymien kohdalla. (Kurki 2005, 179; vokaaliyhtymien kehityksestä ks. myös Rapola 1966, 413-427.)

Painoton vokaaliyhtymä $e A$ voi edustua murteissa seuraavasti: 1) Vokaaliyhtymän vokaalien $e$ ja $A$ välinen laatuero on suurentunut ja todennäköisesti niiden välinen tavunraja on korostunut: korkea > korkia. Vokaalien väliin tuleva $j$ voi näissä tapauksissa korostaa tavunrajaa. Tällä variantilla on laaja läntinen levikki, ja sitä esiintyy myös LounaisSuomen murteissa sekä kaakkoishämäläisissä murteissa. 2) Vokaaliyhtymän vokaalien välinen laatuero on hävinnyt, samoin niiden välissä oleva tavunraja: korkea > korkee. Tämä variantti on tavallinen hämäläis-satakuntalaisissa murteissa ja savolaisilla murrealueilla. Lisäksi sitä esiintyy läntisessä Peräpohjassa. 3) Vokaalit ovat jääneet muuttumatta, ja tavunraja on jäänyt paikoilleen tai hävinnyt. Tätä varianttia esiintyy Lahden-Heinolan seudulla, Keski-Suomessa, Kainuussa ja Peräpohjan länsiosissa. (Wiik 2006, 155-157.)

Painottomasta $O A$-vokaaliyhtymästä on vastaavat ryhmät: verkkua, verkkoo ja verkkoa. Lounais-Suomen verkko-variantti lasketaan kuuluvaksi vokaaliyhtymän kannalta verkkoo-tyyppiin. (Wiik 2006, 157-158.)

Painottomat vokaaliyhtymät $i A$ ja $U A$ jakautuvat suomen murteissa kahteen päävarianttiin: Ensimmäisessä tapahtuu muutos pitkäksi vokaaliksi: $i A>i i$ ja $U A>u u, y y$. Toisessa vokaalit ovat jääneet muuttumatta, jolloin myös tavunraja on usein jäänyt paikoilleen. Monoftongiutuneen muodon levikki alkaa Porin kohdalta ja kulkee Turun ja Uudenmaan kautta Kotkaan. Kotkan ja Viipurin välille jää yleiskielisen variantin alue. Sen jälkeen monoftongiutunutta varianttia esiintyy jälleen Joensuuhun ja Nurmekseen asti. Ilmiön alkualue saattaa Wiikin mukaan olla Lounais-Suomessa. (Wiik 2006, 159-160.)

Nykyisessä Turun murteessa $e A$-vokaaliyhtymän variantti on Wiikin $(1998,40,101)$ mukaan $i A$, mutta hän toteaa, että $e e$-variantti yleistyy koko ajan. Uudemman tutkimuksen mukaan Turun murteessa suurin osa $e A$-vokaaliyhtymän edustuksista on monoftongiutunutta $e e$-varianttia. Variantit $e A$ ja $i A$ ovat siihen nähden harvinaisia. (Ollilainen 2008, 68; Käpylä 2012, 8.) Monoftongiutuneen variantin käyttöä on arveltu nykypuhekielessä lekseemisidonnaiseksi (hirvee, kauhee ja oikeestaan), mutta murteissa sanastolla ei näytä olevan juurikaan merkitystä variantin käyttöön (Mielikäinen 1991, 36).

Monoftongiutuminen on Turun murteessa tyypillistä myös muille vokaaliyhtymille. $U A$ - ja $i A$-vokaaliyhtymät ovat monoftongiutuneita 70-88 prosentissa Kristiina Lindbergin aineiston esiintymistä. Myös Maiju Ollilaisen aineistossa monoftongiutuneita variantteja on enemmän kuin yleiskielisiä variantteja. Ollilaisen työssä tarkastellaan lisäksi $O A$ yhtymää, ja suurin osa näistäkin yhtymistä on monoftongiutuneita Turun puhekielessä. (Lindberg 2005, 50; Ollilainen 2008, 70-72.) 
Renvall kirjoittaa kieliopissaan vokaaliyhtymien oikenemisesta ja toteaa piirteen olevan turunmurteinen. Piirrettä käsitellään ensinnäkin partitiivin yhteydessä. Renvall esittää, että suomen kielessä kaksitavuisen $A$-loppuisen sanan yksikön partitiivi muodostetaan siten, että loppuvokaali pitenee. Turun murteessa yksikön partitiivissa pidennetään myös muut loppuvokaalit kuin $a$ ja $\ddot{a}$, kuten taloo (taloa), wiluu, kiwee. Samoin monikon partitiivi on kiwii (kiviä), kylii. Renvall toteaa, että paremmissa murteissa ei esiinny tällaista: "De bättre dialecterna älska ännu icke ett slikt sammandrag." (Renvall 1840, 45.)

Vokaaliyhtymien muuttuminen pitkiksi vokaaleiksi tulee esille myös Renvallin käsitellessä verbejä: Turun murteessa A-infinitiivien vokaaliyhtymät -oah, -uah, -öäh, -yäh, -eah, -eäh, -iah ja -iäh muuttuvat usein pitkiksi vokaaleiksi -ooh, -uuh, -ööh, -yyh, -eeh, -iih (kuten sanooh, kysyyh) samalla tavalla kuin nominien partitiivit. Tällaista ei saa Renvallin mukaan alkaa käyttää kirjakielessä. (Renvall 1840, 92.) Lisäksi Renvall toteaa, että itseh-pronominin partitiivi on Turun murteessa itseä, muissa murteissa itsiä (Renvall 1840, 78).

Renvallin esimerkkien joukossa on kaikkien vokaaliyhtymien muuttumista pitkiksi vokaaleiksi. Monoftongituneen ee:n sijaan iA olisi lounaismurteisena varianttina odotuksenmukainen. Hämäläismurteiden vaikutus Turun murteeseen näkyy näissä monoftongiutumistapauksissa.

Vokaaliyhtymien vakiintuminen nykyiseen kirjoitusasuun tapahtuu kirjakielessä vasta 1800-luvulla. Vanhassa kirjakielessä ja 1800-luvun kielessä esiintyy nykyvarianttien ohella avartuneita vokaaliyhtymiä ja monoftongiutuneita variantteja. (Lehikoinen-Kiuru 2009, 114-118.)

\subsubsection{Kannan i:n ja suffiksin i:n liitos}

Jos kannan loppuvokaalia $i$ seuraa $i$ :llä alkava suffiksi, vokaalijono $i$ - $i$ on kehittynyt eri murrealueilla eri tavoin. Esimerkiksi monikkomuoto risti-i-llä ja verbin imperfekti repi-i ovat tällaisia muotoja. Suomen murteissa liitoskohdassa $i$ - $i$ voi olla $i$ (monilla ristillä), ii (monilla ristiillä) tai ei (monilla risteillä). Muotoa ei edustavat myös siitä kehittyneet ee (monilla risteellä) ja e (monilla ristellä). (Wiik 2006, 161-162.) Turun murteessa vokaalijonon vastine on ei. ei-muotoa käytetään lounaismurteissa, lounaisissa välimurteissa, keski- ja pohjoispohjalaisissa murteissa sekä pienessä osassa savolaismurteita. Se on myös suomen yleiskielen mukainen vastine, mutta murteissa yleisin variantti on $i$. (Rapola 1920, 160; Wiik 2006, 161-162.)

Renvall toteaa kieliopissaan, että esimerkiksi sanat pappi, sonni ja pilli, joissa on loppuvokaali - $i$ ja monikossa -it, ovat samanmuotoisia monessa yksikön ja monikon sijassa, kuten pappia, pappina, papiksi, pappiin. Vain raamatunkääntäjät ja Turun murteen puhujat ovat huomanneet tämän epäkohdan ja yrittäneet erottaa monikon yksiköstä $i$-vokaalien väliin tulevalla e:llä, kuten pappeja, pappeina, papeiksi, pappeihin. Renvallin mukaan tätä ei pidä tuomita vahvasti, sillä "kieli rakastaa monikon eri muotoja". (Renvall 1840, 61-62.) Vanhassa kirjasuomessa $i$-vartaloisten sanojen monikossa esiintyi ei-diftongin 
lisäksi pelkän $i$ :nkin sisältäviä muotoja 1800-luvulle asti, mutta kirjasuomessa $e i$-diftongi osoittautui ilmeisesti selvyytensä takia kaikkein voitokkaimmaksi variantiksi.

Renvallin mukaan yksikkö ja monikko ovat samannäköisiä monissa sijamuodoissa myös -is-loppuisissa sanoissa (monikossa -ihit tai -iit), kuten nauris : nauriina : nauriiksi : nauriista. Raamatun kielessä ja Turun murteessa yritetään välttää muotojen sekaantumista monikon e:n avulla, kuten naureina, naureiksi, naureista. Myös superlatiivi on Turun murteessa muodossa kaunein tai kaunehin (eikä kauniin tai kaunihin), jottei se sekaantuisi yksikön genetiiviin. (Renvall 1840, 64, 71.) Kaunehin- ja kaunihin-muodoissa on lyhyen vokaalin jäljessä säilynyt $h$. Vanhassa kirjasuomessa esiintyy kumpaakin superlatiivin muotoa. Vielä monissa 1800-luvun kieliopeissa neuvotaan muodostamaan superlatiivit kauni(h)in-tyyppisiksi. (Häkkinen 1994, 229.)

Renvall kirjoittaa kieliopissaan turunmurteisista ei-diftongin sisältävistä muodoista myös in-loppuisten verbien yhteydessä. Renvallin mukaan verbit sowin, kuorin ym. ja nain, woin ja uin ovat useimmissa murteissa samannäköisiä preesensissä ja imperfektissä. Vain Turun murteessa yritetään erottaa imperfekti preesensistä e:llä, kuten sowein, kuorein ja naein, woein, uein. (Renvall 1840, 104, 106.) Vanhassa kirjasuomessa etenkin 1600-luvulta alkaen $i$-vartaloisissa verbeissä vartalovokaali on yleisesti vaihtunut $e$ :ksi, kuten etsei, sodei. (Häkkinen 1994, 271.)

Turun nykymurteelle ja laajemminkin lounaismurteille tyypillinen piirre on laajentunut $s i$-imperfektin käyttö. Muutoksen $i>$ ei lisäksi si-imperfektiä käytetään erottamaan imperfekti preesensistä, kuten sopisin ja repisin. (Wiik 1998, 23-25; Rantala 2016, 29-32.) Renvallin kieliopissa laajentunutta $s i$-imperfektin käyttöä ei kuitenkaan mainita.

\subsubsection{Karitiivin i:n imitaatio}

Kaikkien edellä mainittujen vokaaleja koskevien murrepiirteiden lisäksi Renvall esittää kieliopissaan, että Turun murteessa on sanan sisällä nominatiivi- ja partitiivimuodossa usein $i$, kuten awain, sierain, laiduin, eläin, istuin (partitiivissa awainta, sierainta, laiduinta, eläintä, istuinta). Tätä i:tä ei Renvallin mukaan ole muissa sijoissa, ja hän katsoo sen olevan tarpeeton karitiivien, kuten halutoin, imitaatio. (Renvall 1840, 64.)

Avain, eläin, istuin ja sierain ovat $i$ :llisiä suomen yleiskielessä. Avain-, eläin- ja istuin-

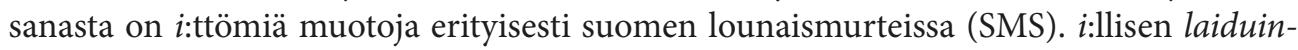
sanan sijaan nykysuomessa ja useimmissa murteissa on käytössä laidun. SMSV:n (s.v. laidun) mukaan laiduin-muotoa esiintyy Etelä-Pohjanmaalla, Merikarvialla ja Nurmijärvellä. Ainakin 1700-luvulle asti kirjakielessä esiintyy näistä sanoista molempia variantteja (VKS). 


\subsection{Konsonantteja koskevat murrepiirteet}

\subsubsection{Sananalkuinen kaksikonsonanttisuus}

Suomen kielessä ei ole alkuaan ollut kahta konsonanttia sanan alussa. Sananalkuista kaksikonsonanttisuutta alkoi esiintyä kielessä ruotsista tulleiden lainasanojen myötä. Vielä 1200- ja 1300-luvuilla tällaiset sanat olivat harvinaisia lounaissuomalaisellakin murrealueella. Turun murteeseen sananalkuinen kaksikonsonanttisuus on omaksuttu kuitenkin jo varhaiskeskiajalla, mutta murteenpuhujilla on vaihtelua näiden ja hämäläis-yleiskielisten varianttien välillä. Sananalkuiset konsonanttiyhtymät tulivat kieleen pääasiassa kaupunkien kautta, ja ne on totuttu yhdistämään kaupunkilaisten puheeseen. (Grönholm 1988, 20; Wiik 2006, 108.)

Nykysuomessa sananalkuiset kahden konsonantin yhtymät, joissa on klusiili ja resonantti, kuten $k l-, k r-, p l$ - ja pr-, ovat tyypillisiä lounaismurteille, mutta niitä esiintyy myös muualla länsimurteissa ja itämurteissakin, sillä sananalkuisia kahden konsonantin yhtymiä on tullut suomeen myös idästä. Pienillä alueilla länsimurteissa ja hieman laajemmalla alueella itämurteissa esiintyy myös yhtymiä $s k$-, st-, sp- jne. (Wiik 2006, 108-109.) Nykyisessä Turun murteessa esiintyy sananalkuista kaksi- ja myös kolmekonsonanttisuutta monissa sellaisissakin sanoissa, joissa yleiskielessä on yksi konsonantti, kuten fläski, skruuvi ja knappi (Wiik 1998, 78).

Renvall $(1840,20)$ toteaa kieliopissaan, ettei suomen kielessä ole konsonanttiyhtymiä sanan alussa eikä lopussa. Puhtaassa suomen kielessä jätetään ensimmäinen konsonantti pois lainasanoista, joissa on useampi konsonantti sanan alussa, kuten rapu (krabba). Vain Turun murteessa on alettu käyttää useampaa konsonanttia sanan alussa, kuten krapu ja preiwi, mutta edes turkulaiset eivät Renvallin mukaan pysty sanomaan sanoja, jotka alkavat konsonanttiyhtymällä sk, sp, st, sm, sn, joten he sanovat tuoli (stol) ja peili (spegel). Myös vanhassa kirjasuomessa ja 1800-luvun kirjakielessä esiintyy nykysuomesta poikkeavia konsonanttiyhtymällä alkavia sanoja, kuten krapu, krapina ja kriimu (VKS).

\subsection{2. $\mathrm{k}: n$ radikaalinen astevaihtelu}

Astevaihtelussa varhaiskantasuomen soinnittomat klusiilit $k, p$ ja $t$ heikkenevät ympäristöissä, joissa niiden aloittama tavu on "liian painollinen" suhteessa edeltävään tavuun. Painottoman tavun alussa oleva soinniton klusiili muuttuu heikoksi vastineekseen radikaaliastevaihtelussa, jossa toinen tavu päättyy konsonanttiin, ja suffiksaaliastevaihtelussa, jossa kolmas tavu seuraa painotonta lyhyttä toista tavua. Astevaihtelun periaatteet ovat samat suomen eri murteissa, mutta klusiilien heikkojen vastineiden jälkeläiset voivat olla hyvin erilaisia eri puolella Suomea. Kun tarkastellaan astevaihtelua, keskeistä on se, millainen äänne edeltää ja seuraa klusiilia. (Wiik 2006, 30-31.)

Renvall kirjoittaa kieliopissaan, että astevaihtelun alainen $k$ muuttuu Länsi-Suomessa ja erityisesti Turun alueella puolivokaali j:ksi tai $w$ :ksi varsinkin, jos peräkkäin olisi kolme vokaalia tai kaksi vokaalia esiintyisi diftongina. (Renvall 1840, 26.) Tarkastelen seuraavaksi niitä astevaihtelutapauksia, jotka esiintyvät Renvallin kieliopissa. 


\section{$k$ pitkän vokaalin tai diftongin jäljessä}

Suomen kielessä $i$-loppuisen diftongin jäljessä oleva $k$ :n heikko aste $\gamma$ on kadonnut, ja tämän jälkeen diftongin $i$ on siirtynyt toisen tavun alkuun konsonantin funktioon, kuten aika : ajan, poika : pojan. Nykysuomessa on myös sellaisia sanoja, joissa on tapahtunut muutos $\gamma>$ kato, mutta $i$ ei ole ylittänyt tavunrajaa, kuten taika : taian, oikenee : oieta. Ääntämistapa taijan, oijeta on luonteva ja kansan puhekielen mukainen. (Rapola 1966, 68.) Renvall mainitsee kieliopissaan länsisuomalaisina ja Turun alueelle tyypillisinä j:lliset heikon asteen vastineet sanoissa reikä : reijät ja oikenen : oijetah (Renvall 1840, 26).

Yleiskielen ruoan/ruuan-tyyppisten muotojen heikon asteen vastineet voivat olla suomen murteissa pitkä- tai lyhytvokaalisia. Lyhytvokaaliset variantit (ru.an, ru.aan, ruvaan, ruvvaan) esiintyvät länsimurteiden alueella, itämurteissa vokaali on pitkä (ruuvan, ruuvvan, ruu.an, ruvan). Suurimpana poikkeuksena päämurrejaon mukaisesta esiintymästä on Päijät-Hämeen murre, joka kuuluu itämurteisiin mutta jossa käytetään kuitenkin lyhytvokaalisia muotoja. (Wiik 2006, 51-54.) Renvallilla kieliopissa esiintyy länsimurteisena ja erityisesti Turun alueelle tyypillisenä $k: n$ astevaihtelutapaus huokaan : huowatah (Renvall 1840, 26).

Rapolan $(1966,68)$ mukaan $u$-loppuisen diftongin jäljessä olevan $k$ :n heikon asteen $\gamma:$ n edustus on hyvin yhtenäinen suomen kielessä. Tavallisin ääntämistapa on $v$ :llinen. Renvallin kieliopissa esitetään länsimurteisina ja Turun alueen puheelle tyypillisinä $k: n$ astevaihtelutapaukset kouko : kouwot, hauki : hauwit, leuka : leuwat. Laajasta levikistä huolimatta Renvall pitää näitä muotoja länsisuomalaisina ja erityisesti Turun alueen kielelle tyypillisinä. (Renvall 1840, 26.)

\section{$k$ lyhyiden vokaalien välissä}

Suomen murteissa ei ole vaihtelua, jos $k$ :n heikko vastine on kahden $u$ :n tai $y: n$ välissä. $k$ :n heikko vastine on näissä tapauksissa kaikissa murteissa $v$, kuten puku : puvun. (Wiik 2006, 34.) Renvall $(1840,26)$ kuitenkin esittää vaihtelun suku : suwut länsimurteiseksi ja erityisesti Turun alueella esiintyväksi.

Kun $k: n$ heikko vastine on illabiaalisen ja labiaalisen vokaalin välissä, sillä on kolmenlaisia vastineita murteissa: 1) $k$ :n heikko vastine on kadonnut, mutta sen paikalla on tavunraja (ra.ot, te.ot). Tämä variantti esiintyy Lounais-Suomessa, läntisessä Peräpohjassa ja Hollolan ryhmässä. 2) Sekä heikko vastine että sen kohdalla ollut tavunraja ovat kadonneet ja vokaalit ovat sulautuneet diftongiksi (raot, raut, teot, teut). Variantti esiintyy pohjoisessa Savossa, Etelä-Pohjanmaalla ja kaakkoismurteiden alueella. 3) Heikkona varianttina on puolivokaali $v$ (ravot, tevot). Tätä varianttia esiintyy suurimmassa osassa hämäläisaluetta, eteläisessä Savossa, kaakkoishämäläisellä alueella ja lounaisten välimurteiden alueella. Lisäksi sitä esiintyy pohjalaisalueella ja Peräpohjassa. (Wiik 2006, 48-49.) Renvallin kieliopissa on esitetty länsimurteisina ja Turun alueen kielelle tyypillisinä v:lliset variantit, jotka ovat tyypillisiä siis muun muassa hämäläismurteille ja lounaisille välimurteille: rako : rawot, maku : mawut, näkö : näwöt (mt. 1840, 26). 
Radikaalisessa astevaihtelussa $k$ :n heikot vastineet ympäristöissä $a \_e$ ja $\ddot{a} \_e$ ovat moninaiset suomen murteissa. Lounais-Suomessa vokaalit eivät muodosta diftongia, vaan niiden välinen tavunraja on säilynyt (mä.en). Hämeessä ja Pohjanmaalla sekä suuressa osassa Peräpohjaa $k$ :n heikkona vastineena on j: mäjen. (Wiik 2006, 39-40, jossa esitettynä myös muiden murteiden edustukset.) Renvallin kieliopissa tätä astevaihtelutapausta edustaa rakeet : rajeh, jonka Renvall $(1840,26)$ katsoo länsisuomalaiseksi ja erityisesti Turun alueella esiintyväksi. Tässäkin näkyy hämäläismurteiden vaikutus Turun murteeseen.

k:n astevaihtelu muun muassa sanoissa hajen, näjen, lujen on Rapolan mukaan hämäläismurteista, vaikka sitä on muillakin murrealueilla, esimerkiksi Pohjanmaalla (Rapola 1969, 120). Renvallin kieliopissa esitetään länsisuomalaisina ja Turun alueelle tyypillisinä luki : lujin ja näki : näjin Toisaalta Renvall kirjoittaa toisaalla kieliopissaan, että lukea-verbi on vahva-asteinen Turun murteessa imperfektin yksikön 3. persoonassa (luki) ja konditionaalissa (lukisin), mitä hän pitää poikkeuksena, anomaliana. Lisäksi hän mainitsee seuraavan $k: n$ astevaihtelutapauksen, jossa $k: n$ heikkona asteena on $j$ : laki : lajit. (Renvall $1840,26,101)$.

Yleiskielen ruis : rukiin -sanalla on suomen murteissa kaksi varianttia. $k$ :n heikko vastine on joko hävinnyt tai sitä edustaa puolivokaali $v$. Ruvis on käytössä Lounais-Suomessa, Etelä-Hämeessä, Ylä-Satakunnassa, Keski- ja Pohjois-Pohjanmaalla, Kainuussa ja lähes koko Peräpohjassa. (Rapola 1966, 56; Wiik 2006, 48.) Renvallin kieliopissa ruwis, rukiit esitetään länsimurteisena ja Turun alueen murteelle tyypillisenä. Lisäksi länsimurteille ja Turun alueen kielelle todetaan tyypilliseksi j:llinen heikko aste sanassa ikä : ijät. (Mt. 1840, 26.) Vanhassa kirjasuomessa ensi tavun $i$ :n jäljessä oleva $k$ on heikkoasteisena usein $j$, kuten kyseisessä sanassa ijällä. Kirjakielen syntyaikoina $k$ :n heikkoasteinen pari on ollut soinnillinen dentaalispirantti (tekstissä merkitty $g: l l a ̈, ~ g h: l l a ~ t a i ~ g h i: 1 l a) . ~ k: n$ heikko aste vakiintui kirjakielessä nykyiselleen melko varhain. $l k$ - ja $r k$-yhtymän heikossa asteessa oli kuitenkin nykyisestä poiketen lj ja rj, kuten näljän, härjän. Näissä nykyedustukseen päädyttiin vasta 1800-luvulla. (Lehikoinen-Kiuru 2009, 97; Häkkinen 1994, 166.)

\subsubsection{Heikkoasteiset imperfekti- ja konditionaalimuodot}

Lounaismurteissa ja lounaisissa siirtymämurteissa esiintyy yleiskielen astevaihtelusta poikkeavaa heikkoasteisuutta imperfektissä ja konditionaalissa, kuten annoi (antoi) ja soveisin (sopisin). Lounais-Suomen murteissa $i$ on voinut sulkea tavun konsonantin tapaan, jolloin tavun alussa on heikko aste. Yleiskielessä sen sijaan on vahva aste, koska vokaaliin päättyvä tavu on avotavu. $i$-vartaloisten verbien imperfekti- ja konditionaalimuodoissa on konsonanttiaineksen eron lisäksi ero myös sitä seuraavassa vokaaliaineksessa. ei-diftongi vaihtelee näissä murteissa yleiskielisen $i$ - (ja myös $e$-) edustuksen kanssa. (Ojansuu 1901, 208, 213; Rapola 1920, 157-160; Rapola 1966, 41-43; Kurki ym. 2011, 98-99, 101-105.)

Turun murteessa on Renvallin $(1840,101)$ mukaan toisinaan pehmeämpi konsonantti imperfektin 3. persoonassa ja koko konditionaalissa, kuten annoi, nukui, annaisin, nukuisin, muiden murteiden antoi, nukkui, antaisin, nukkuisin sijaan. Poikkeuksellista 
heikkoasteisuutta ja ei-diftongia esiintyy myös vanhassa kirjasuomessa. $i$-vartaloisten verbien diftongilliset muodot väistyvät kirjasuomesta 1800-luvulla (Lehtinen 2007, 255).

\subsection{4. h:n metateesi}

Lounais-Suomen murteissa lyhyen vokaalin jälkeinen $h$ on voinut siirtyä metateettisesti edellisen tavun vokaalin eteen. Metateesia on myös $h$-loppuisten sanojen nominatiivissa. Metateettisia muotoja ovat esimerkiksi valehtelen $>$ valhettelen ja unohtaa $>$ unhottaa. (Wiik 2006, 116.) Kettusen (1928, 126, 128-129) mukaan sellaiset lounaismurteiset muodot kuin unhottaa ja erhakko osoittavat, että tavunalkuinen $h$ on syntynyt tavunloppuisen $h$ :n vaikutuksesta. Lounaissuomalaista edustusta, joissa ensi tavu on ollut lyhyt ja toinen on alkanut $n, m, l, r$ tai $i$-äänteellä, voidaan pitää $h$ :n ennakkoääntämisenä toisen tavun alussa (venehen > venhehen) tai metateesina (venehen > venhe-en > venhen). Sen sijaan muissa murteissa esiintyvä kahden samanlaisen tai erilaisen vokaalin välissä oleva $h$ selittyy sisäheitoksi (rikkahat > rikhat, venehet > venhet). Lisäksi Kettunen toteaa, että "regressiivistä $h$-tartuntaa" tai metateesia on kenties tapahtunut myös toista tavua aloittavan $h: n$ vaikutuksesta, kuten alahalla > alhahalla tai alha-alla. Wiikin $(1998,74)$ mukaan Turun nykymurteessa esiintyy metateettisia muotoja.

Renvall kirjoittaa, että Turun murteessa ja Raamatussa $h$ on tietyissä sanoissa eri kohdassa kuin muussa kielessä. Turun murteessa voi olla peräkkäin $r h$, lh ja $n h$, kuten murhe, walhe ja wenhe (monikossa murheet, walheet ja wenheet). Muissa murteissa, joissa vältetään kyseisiä konsonanttiyhtymiä, on mureh, waleh ja weneh (monikossa mure(h)et, wale(h)et ja wene(h)et). Vastaavasti Turun murteessa monikkomuodot sanoista puras 'naskali, piikki', paras sekä alas ja ylös ovat purhaat, parhaat, alhaalla ja ylhäällä, muissa murteissa pura(h)at, para(h)at, alaalla, yläällä. Lisäksi Renvall toteaa, että $h$ säilyy vastaavalla tavalla sanojen muissa sijamuodoissa, kuten murheeksi, murheella, murheita, ja sanojen johdoksissa, kuten murheellinen, walhettelen, alhainen. (Renvall 1840, 44-45.) Vanhassa kirjasuomessa esiintyy metateettisia muotoja, ja 1600-luvulta alkaen ne ovat kirjakielen normaaleja muotoja. Niitä esiintyy myös 1800-luvun kirjakielessä. (Lehikoinen-Kiuru 2009, 110.)

\subsubsection{Sananloppuisen t:n katoaminen}

Sanan lopussa on $t$ :n sijaan seuraavan konsonantin kertauma, kun seuraava sana alkaa $k$ :lla, t:llä, p:llä tai s:1lä, kuten pitkäs seippä (pitkät seipäät). Länsimurteissa on laajemminkin loppu-t:n katoa ja seuraavaan konsonanttiin mukautumista esimerkiksi sanoissa kevä $(t)$, olu(t), $n y(t)$ ja aktiivin toisen partisiipin nominatiivissa, kuten ollu ja sanonu. (Rapola 1969, 110.)

Renvall kiinnittää kieliopissaan huomiota sanoihin, joissa on loppu-t:n katoa. Hänen mukaansa oluh- tai olut-tyyppiset sanat, joissa on lopussa - uh tai - yh ja monikossa -uet tai -yet, supistuvat Turun murteessa: olu, ohu, lyhy, neitsy. Sanat taipuvat Renvallin mukaan sanojen talo ja tyly mukaisesti. (Renvall 1840, 65.) Loppu-t:n katoa esiintyy kyseisissä sanoissa myös vanhassa kirjasuomessa. 


\subsection{Yksittäisiä sanoja koskevat murrepiirteet}

\subsubsection{Persoonapronominit minä ja sinä}

Persoonapronominit minä ja sinä edustuvat suomen murteissa kolmenlaisesti: 1) hämäläis-savolainen minä/mä, 2) lounaissuomalainen mää/mnää ja 3) karjalainen mie (miä, $m e \ddot{a})$, jota käytetään myös Peräpohjan länsiosassa ja eteläsavolaisella ja kaakkoishämäläisellä alueella. (Wiik 2006, 184-185.)

Turun murteessa esiintyy lounaissuomalaisen mää-variantin lisäksi hämäläis-savolainen $m \ddot{a}$-variantti, joka onkin itse asiassa huomattavasti yleisempi kuin mää tai yleiskielinen minä (Ollilainen 2008, 56). Varianttien mä ja mää erottaminen on vaikeaa, ja toisinaan niitä ei edes yritetä erottaa omiksi varianteikseen (ks. esim. Suojanen 1985, 29-31, 49-54).

Renvall toteaa kieliopissaan, että minä supistuu Turun murteessa toisinaan muotoon mä (mun, mua, muna). Sinä on Turun murteessa vastaavasti sä, sun, suna. (Mt. 1840, 76-77.) Variantti $m \ddot{a}$, sä on alkuaan hämäläis-savolainen, ja näin ollen se on levinnyt hämäläismurteista Turun murteeseen. Lounaismurteissa käytetään sen sijaan pääsääntöisesti muotoa $m(n) \ddot{a ̈}$. Yksikön 1. ja 2. persoonan pronominit ovat esiintyneet 1500-luvulta alkaen myös kirjasuomessa muodoissa mä ja sä (Häkkinen 1994, 233).

\subsubsection{Pronomini tuo}

Yleiskielen tuo-pronominilla ${ }^{4}$ on hämäläinen murrevastine toi (monikossa noi). Toi esiintyy muissa hämäläismurteissa paitsi satakuntalaisissa murteissa sekä savolaisessa PäijätHämeen murteessa, osassa Etelä-Savon murteita ja osassa Lounais-Suomen pohjois- ja itäryhmää. Lounais-Suomessa toi-pronominin alue muodostaa ikään kuin leventyneen hämäläiskiilan, joka kulkee Hämeestä Turkuun. Toi leviää nopeasti nykypuhekielessä. (Kettunen 1940, kartta 157; Mielikäinen 1991, 30; Wiik 2006, 185-186.)

Renvall $(1840,77)$ pitää pronominin tuo muotoja toi, toin, tota jne. (monikossa noit) turunmurteisina. Alkuaan hämäläismurteista toi-varianttia esiintyy nykyäänkin Turun murteessa. Pronominit tuo ja nuo ovat tulleet kirjakieleen vasta 1600 -luvulla, ja aluksi ne olivat yleensä muodoissa toi ja noi (Häkkinen 1994, 236).

\subsubsection{Adpositiot ja adverbit}

Renvall toteaa kieliopissaan, että erityisesti Turun murteessa käytetään ruotsin kielen "järjettömän matkimisen tähden" osaa lokatiivisista prepositioista väärin, niiden oman alkuperäisen merkityksen vastaisesti. Kun kielenkäyttäjät huomasivat, että jokin ruotsin prepositio vastaa tiettyä suomen prepositiota, he ajattelivat, että ruotsin ja suomen

4 Hän, se, tää ja toi -pronominien käytöstä Kaakkois-Satakunnan nykypuhekielessä vuorovaikutussosiolingvistisesta näkökulmasta Priiki 2017. 
prepositiot ovat samanlaisia kaikissa merkityksen vivahteissa. Ruotsin ja suomen prepositioita alettiin käyttää synonyymisesti, vaikka tietyt ruotsin prepositioiden merkitykset olisivat vaatineet suomessa sijamuotojen käyttöä. (Renvall 1840, 125.)

Renvall nostaa esille ruotsinmukaiset esi- ja pää-vartaloisten adpositioiden käytöt. Suomen edestä, edessä vastaa ruotsin för-prepositiota Renvallin mukaan vain silloin, kun se on samanmerkityksinen framför- ja inför-prepositioiden kanssa (lat. ante, coram), jolloin adpositiorakenteella ilmaistaan edessä olevaa tilaa tai paikkaa. Vastaavasti päällä vastaa ruotsin på-prepositiota vain, kun se merkitsee 'ovan på, ofvanföre, utanpå’ (lat. super). Renvallin mielestä Turun murteen puhujat ovat tehneet edestä- ja päällä-sanoista "kohtuuttomasti ja tarpeettomasti” samanmerkityksiset kuin ruotsin för ja på myös silloin, kun kyse ei ole tilasta. Turun murteessa sanotaan esimerkiksi tacka för maten -mallin mukaisesti ruwan edestä (eli 'undanför' tai 'framifrån maten') sen sijaan, että sanottaisiin ruwasta. Ruotsin betala för sin son -mallin mukaan Turussa sanotaan poikas edestä ('undanför din son') eikä poikas puolesta, siassa tai tähden. Vastaavasti köp för penningar on mallina rakenteelle ostah rahan edestä (par. rahalla). Muita kieliopissa olevia esimerkkejä ovat: tro icke på honom, äläh uskoh hänen päällensäh (par. äläh uskoh häntä), förlita sig på något, luottaa tai turwatah sen päälleh (par. luotta siehen), vara på visit, ollah wisitin päällä!!! Kieliopissa tämä on ainoa Turun murretta käsittelevä kohta, johon Renvall on laittanut kolme huutomerkkiä, mikä kertoo, että kyseessä on Renvallin mielestä kaikkein pöyristyttävin Turun murteen piirre. Tämän jälkeen kirjoittaja jatkaa, että nämä Turun murteessa esiintyvät prepositioiden väärät käyttötavat ovat vähitellen pesiytyneet moniin Turun murretta puhtaampiin murteisiin ja erityisesti kirkon kieleen. (Renvall 1840, 125-126.)

Rakenne uskoa jonkin päälle onkin yleinen vanhassa uskonnollisessa kielessä. Agricolan kielessä se on niin yleinen, että sitä voi pitää leksikaalistuneena. Monelle Agricolan kielen vieraalle adpositiorakenteelle on vastine useammassakin lähdekielessä, mutta uskoa jonkin päälle -rakenteen mallina on Renvallin mainitsema tro på. (Salmi 2010, 225.) August Ahlqvist pitää rakennetta uskoa jonkin päälle niin vakiintuneena hengelliseen kieleen, että se on hänen mukaansa hyväksyttävää kielenkäyttöä (Kohtamäki 1956, 169-170).

Myös luottaa ja turvata jonkin päälle -rakenteet ovat leksikaalistuneet Agricolan kielessä. Renvallin mainitseman ruotsinkielisen esikuvan lisäksi saksan vastaava rakenne verlassen (sich) auff on voinut toimia mallina näille rakenteille, samoin kreikan kielen

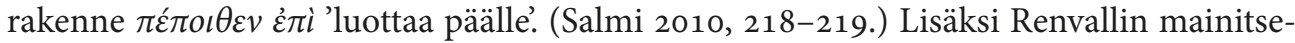
mista edessä-adpositiorakenteista kiittää jonkin edestä ja maksaa jonkin edestä esiintyvät Agricolan kielessä (Inaba ym. 2008).

\subsubsection{Muut $y k$ sittäiset sanat}

Suomen kielen pois-sana palautuu myöhäiskantasuomalaiseen muotoon ${ }^{\star}$ poijes. Pois on lyhentynyt Lauri Hakulisen $(1979,109)$ mukaan muodosta poi(j)es, kun tavunraja on hävinnyt ja $e$ on sulautunut edeltävään diftongiin. Martti Rapola $(1966,380)$ esittää seuraavanlaisen kehityksen: poies $>$ pojes $>{ }^{*}$ poes $>$ pois. Muotoa poijes esiintyy nykyäänkin länsimurteissa (SMSA), kuten eikä päässyp poijes siittä arkusta (Virtaranta 1957, 71). Renvallin 
(1840, 131) mukaan adverbi pois on Turun murteessa muodossa poijes. Vanhassa kirjasuomessa pois esiintyy myös muodossa poijghes ainakin Agricolan kielessä (Inaba ym. 2008).

Sanojen meri ja veri partitiivimuodot ovat Kettusen murrekartaston (1940, kartta numero 172) mukaan takavokaalisia vertä ja mertä lounaismurteissa mutta myös peräpohjalaisissa murteissa ja osassa savolais- ja kaakkoismurteita. Myös Renvall toteaa saman kieliopissaan. Hänen mukaansa sanat meri ja weri ovat yksikön partitiivissa merta ja werta monissa murteissa. Poikkeuksena tästä ovat Turun murre ja jotkin itämurteet, joissa sanotaan mertä ja wertä, jotka ovatkin Renvallin mukaan vokaaliharmonian kannalta oikeampia muotoja. (Renvall 1840, 62.) Vanhassa kirjasuomessa meri esiintyy ainakin Agricolan teoksissa myös kirjoitusasussa merte, jossa jälkimmäinen $e$ vastaa ä:tä (Inaba ym. 2008).

\section{Yhteenveto}

Nykyiset suomen kieliopit käsittelevät tavallisesti kirjoitettua kieltä ja ovat luonteeltaan normatiivisia. Ison suomen kieliopin (2004) myötä kielioppeihin tulee deskriptiivinen näkökulma ja myös puhekielen piirteet otetaan kieliopin piiriin. Renvall kirjoitti kielioppinsa 180o-luvulla aikana, jolloin käytiin laajaa keskustelua länsi- ja itämurteiden soveltuvuudesta kirjakielen pohjaksi ja murteissa olevien piirteiden sopivuudesta kirjakieleen. Onkin luontevaa, että länsimurteiden puolustajan Renvallin kieliopissa käsitellään kirjakielen ohella myös suomen murteiden erityispiirteitä ja niiden eroja kirjakielisiin muotoihin verrattuna. Kiinnostavan vertailukohdan Renvallin kieliopille tarjoaisi itämurteiden kannattajan Reinhold von Beckerin Finsk Grammatik (1824).

Renvall perustaa kielioppinsa puhtaaseen länsisuomalaiseen kieleen, ja Turun murre edustaa hänen käsityksensä mukaan usein huonoa, turmeltunutta kieltä. Renvallin tapa kirjoittaa Turun murteesta on paikoin hyvin poleeminen, ja hän käsittelee turunmurteisiksi toteamansa piirteet joko neutraalisti tai tuomitsevasti. Vain muutama turunmurteinen piirre on Renvallin mukaan kielen kannalta ymmärrettävä. Kaikkein jyrkimmin sanoin Renvall käsittelee niitä piirteitä, jotka ovat tulleet Turun murteeseen ruotsin kielen vaikutuksesta.

Renvall esittää Turun murretta koskevat näkemyksensä yleensä alaotsikoiden "Anmärkningar (om Dialekt-olikheter)" alla. Murrepiirteiden esittelyä edeltää kunkin ilmiön käsittely varsinaisessa kirjakieltä käsittelevässä muoto-opissa, ja turunmurteiset variantit kontrastoituvat yleiskielisiin variantteihin sekä usein myös muiden murteiden variantteihin. Kieliopissa esitetään turunmurteisten piirteiden lisäksi myös länsimurteisia, itämurteisia ja karjalaisia piirteitä sekä satakuntalaisia, hämäläisiä, savolaisia ja kainuulaisia piirteitä. Turku on kuitenkin ainoa yksittäinen paikkakunta, jonka murteen piirteitä kieliopissa käsitellään. Tämä selittynee lounaismurteita edustavan Turun murteen keskeisellä asemalla vanhan kirjakielen pohjana sekä sillä, että Turun murre poikkeaa vieraine piirteineen Renvallin etsimästä puhtaasta länsimurteisesta kielestä. Se on sekamurre, jonka lounaismurteiseen pohjaan on sekoittunut hämäläismurteisia piirteitä, ja myös ruotsin kieli on vaikuttanut siihen paljon. 
Useimmat Renvallin turkulaisiksi esittämät piirteet eivät kuitenkaan ole tyypillisiä pelkästään Turun murteelle, vaan niitä käytetään laajemminkin lounaismurteissa, länsimurteiden alueella tai hämäläismurteissa. Jotkin piirteistä esiintyvät myös osassa itämurteita. Renvallin turunmurteisina pitämistä piirteistä lounais- ja laajemminkin länsimurteisia ovat loppuheitto, kannan $i$ :n ja suffiksin $i$ :n liitoksen muuttuminen ei:ksi, sananalkuinen kaksikonsonanttisuus, sananloppuisen $t: n$ kato, osa $k: n$ astevaihtelutapauksista sekä poissanan variantti poijes. Selvemmin juuri lounaismurteisia ovat $h$ :n metateesi ja heikkoasteiset imperfekti- ja konditionaalimuodot sekä meri- ja veri-sanojen etuvokaaliset taivutusmuodot mertä ja vertä.

Alkuaan hämäläismurteille puolestaan ovat tyypillisiä vokaaliyhtymien monoftongiutuminen, osa $k: n$ astevaihtelutapauksista, persoonapronominien variantit $m a ̈$ ja sä sekä pronominin tuo variantti toi. Nykyisessä murretutkimuksessa Turun murre lasketaan yleisimmin lounaismurteeksi, mutta Turku sijaitsee murteiden risteyskohdassa, ja murteessa on paljon alkuaan hämäläismurteisia piirteitä. Nämä hämäläiset piirteet ovatkin leimallisia Turun murteelle sikäli, että ne erottavat Turun murteen omanlaisekseen muihin lounaismurteisiin verrattuna. Onkin odotuksenmukaista, että Renvall nostaa esille Turun murteen hämäläismurteisia piirteitä juuri turkulaisina, sillä ne poikkeavat muusta lounaismurteesta. Renvall ei kuitenkaan tunnista näitä piirteitä hämäläisiksi vaan pitää niitä nimenomaan turkulaisina.

Erityisesti Turun alueen puhekielelle on ominainen painottomien vokaalien lyheneminen, kuten asuk (asuuko). Sen taustalla on ruotsin kielen vaikutus Turun murteeseen. Ruotsi on taustalla myös sananalkuisten kahden tai useamman konsonantin yhtymissä ja Renvallin turunmurteisina ja erityisen huonoina pitämissä ruotsinmukaisissa adpositioiden käytöissä. Yleiskielisiä tai useimmissa suomen murteissa esiintyviä piirteitä puolestaan ovat Renvallin karitiivin imitaatiotapauksiksi katsomat $i$ :lliset sanat (kuten avain, eläin). $i$ :ttömiä muotoja sen sijaan esiintyy erityisesti lounaismurteiden alueella.

Renvallin turunmurteisiksi esittämät variantit esiintyvät nykytutkimuksen mukaan pääosin edelleenkin Turun murteessa. Ne eivät kuitenkaan ole ainoita Turun murteessa esiintyviä variantteja, vaan piirteissä esiintyy vaihtelua. Esimerkiksi vokaaliyhtymien monoftongiutumisen lisäksi Turun murteessa esiintyy avartumista sekä yleiskielen mukaisiakin variantteja, loppuheitto ei ole ehdoton ja minä-pronominista käytetään variantteja $m a ̈$ ja mää. Joitain yksittäisiä sanoja koskevien piirteiden sekä $k: n$ radikaalisen astevaihtelun osalta tarvittaisiin lisätutkimusta nykyisen Turun murteen osalta.

Renvall huomauttaa muutamassa kohdassa, että jokin variantti esiintyy Turun murteessa mutta myös Raamatussa tai vanhassa virsikirjassa ja hengellisissä lauluissa. Renvallin turunmurteisiksi esittämät variantit ovatkin tyypillisiä myös vanhalle kirjasuomelle ja pääosin vielä $1800-l u v u n$ kirjakielellekin. Useimmat käsitellyistä piirteistä saavat vakiintuneet ja yhteisesti hyväksytyt muotonsa 1800 -luvun kuluessa. Varianttien esiintyminen vanhassa kirjakielessä on voinut osaltaan vaikuttaa siihen, että Renvall on mieltänyt ne turunmurteisiksi eikä laajemmin länsi- tai edes lounaismurteisiksi eikä ainakaan hämäläismurteisiksi. 


\section{Lähteet}

GröNhOlm, MaIjA 1988: Ruotsalaiset lainasanat Turun murteessa. Åbo Akademis förlag, Åbo.

HakUlinen, LAURI 1979: Suomen kielen rakenne ja kehitys. Neljäs, korjattu ja lisätty painos. Otava, Helsinki.

HeIkinheimo, Ilmari 1955: Suomen elämäkerrasto. WSOY, Porvoo.

HÄKKINEN, KAISA 1994: Agricolasta nykykieleen. Suomen kirjakielen historia. WSOY, Juva.

IкоLA, Osмо 1972: Kirjakieli ja puhekieli, yleiskieli ja murre. Sananjalka 14, 16-26.

Inaba, Nobufumi - MerimaA, Heidi - Nummila, Kirsi-Maria - Vaittinen, Tanja 2008: Mikael Agricolan teosten morfosyntaktinen tietokanta. Suomen Akatemia 2004-2007, hankkeen johtaja Kaisa Häkkinen. Lauseopin arkisto, Turun yliopisto ja Kotimaisten kielten keskus, Helsinki.

KetTUnen, LAURI 1928: Ns. $h$ :n metateesi suomen murteissa. Virittäjä, 115-128.

- 1930: Suomen murteet II. Murrealueet. SKST 188. SKS, Helsinki.

1940: Suomen murteet III. A. Murrekartasto. SKS, Helsinki.

КонтAмÄKI, ILMARI 1956: Ankara puutarhuri. August Ahlqvist suomen kielen ja kirjallisuuden arvostelijana. SKST 248. SKS, Helsinki.

Kolehmainen, Taru 2014: Kielenhuollon juurilla. Suomen kielen ohjailun historia. Suomi 204. SKS, Helsinki.

KURKI, TOMmI 2005: Yksilön ja ryhmän kielen reaaliaikainen muuttuminen. Kielenmuutosten seuraamisesta ja niiden tarkastelussa käytettävistä menetelmistä. SKST 1036. SKS, Helsinki.

KäPYLÄ, HANE 2012: Vanhaa ja uutta turkua. Turkulaisten naisten kieltä neljässä sukupolvessa. Pro gradu -tutkielma. Turun yliopiston kieli- ja käännöstieteiden laitos.

Labov, W. 1971: The Study of Language in its Social Context. J. A. Fishman (toim.): Advances in the Sociology of Language I. Basic concepts, theories and problems: alternative approaches, 152-216. Mouton, Hague.

LAINE, Tuija (toim.) 1997: Vanhimman suomalaisen kirjallisuuden käsikirja. SKST686. SKS, Helsinki.

Lauerma, Petri 2004: Aluemurre vai murteiden yhdistelmä? Keskustelu kirjakielen perustasta 1800luvun alkupuolella. Katja Huumo, Lea Laitinen ja Outi Paloposki (toim.): Yhteistä kieltä tekemässä. Näkökulmia suomen kirjakielen kehitykseen 180o-luvulla, 136-176. SKST 979. SKS, Helsinki.

Lehikoinen, Laila - KiURu, Silva 2009: Kirjasuomen kehitys. 7. painos, uudistettu laitos. Hakapaino, Helsinki.

LeHTinen, TAPANi 2007: Kielen vuosituhannet. Suomen kielen kehitys kantauralista varhaissuomeen. Tietolipas 215. SKS, Helsinki.

LINDBERG, Kristina 2005: Miten Turussa puhutaan? Kuuden idiolektin reaaliaikainen muuttuminen 1970-luvulta 200o-luvulle. Pro gradu -tutkielma. Turun yliopiston kieli- ja käännöstieteiden laitos.

MARK, Julius 1949: Die finnische Grammatik von Henricus Crugerus. Finnisch-Ugrische Forschungen XXX, Heft 1-2, 55-146.

MieliKäInen, Aila 1991: Murteiden murros. Levikkikarttoja nykypuhekielen piirteistä. Jyväskylän yliopiston suomen kielen laitoksen julkaisuja 36. Jyväskylän yliopisto, Jyväskylä.

NikкILÄ, Osmo 1994: Loppuheitto ja vanha kirjasuomi. Suomen kielen i:n loppuheiton historiaa. Opera Fennistica \& Linguistica 8. Tampereen yliopiston suomen kielen ja yleisen kielitieteen laitos. Tampere.

OjansuU, HeIkKi 1901: Suomen lounaismurteiden äännehistoria. Vokaalioppi. Helsinki.

_ 1903: Konsonantit. Eripainos aikakauskirjasta "Suomesta". Helsinki.

Ollilainen, MaIju 2008: Yleiskielen ja puhekielen variaatio turkulaisten S1- ja S2-oppilaiden puheessa ja kirjoituksessa. Pro gradu -tutkielma. Turun yliopiston kieli- ja käännöstieteiden laitos.

Palander, Marjatta 1996: Vaihtelu Savonlinnan seudun välimurteissa. SKST 648. SKS, Helsinki.

Palkki, Rittta - Lauerma, Petri - KuUtti, Pirkko 2009: Historiallinen löytö: Rudimenta - uusi suomen varhaiskielioppi. Virittäjä 113, 2-17. 
PrIIKI, KATRI 2017: Hän, se, tää vai toi? Vuorovaikutussosiolingvistinen tutkimus henkilöviittauksista Kaakkois-Satakunnan nykypuhekielessä. Turun yliopiston julkaisuja C 432. Turun yliopisto, Turku.

Ranta, RaImo 1975: Turun kaupungin historia 1600-1721 I-II. Turku.

Rantala, Henna 2016: Mää puhusi hänel ihan tommotti noi. Laajentuneen si-imperfektin käyttö ja sananloppuisen n:n kato Turun puhekielessä 1970-luvulta 200o-luvulle. Pro gradu -tutkielma. Turun yliopiston kieli- ja käännöstieteiden laitos.

RAPOLA, MARTTI 1920: Kantasuomalaiset pääpainottomain tavujen i-loppuiset diftongit suomen murteissa. SKS, Helsinki.

—_ 1966: Suomen kielen äännehistorian luennot. SKST 283. SKS, Helsinki. 1969: Johdatus suomen murteisiin. Kolmas painos. Tietolipas 4. SKS, Helsinki.

SaAri, Mirja 1980: Kieli ja yhteiskunta. Kari SajavaAra (toim.): Soveltava kielitiede, 25-35. Huhmari.

SALMI, HeIDI 2010: Mikael Agricolan teosten kielen ala-, ylä- ja pää-vartaloiset adpositiot. Turun yliopiston julkaisuja C 307. Turun yliopisto, Turku. https://www.doria.fi/handle/10024/66658.

SalomaA, Leena 1979: Loppuheitto Turun puhekielessä. Pro gradu -tutkielma. Turun yliopiston suomalaisen ja yleisen kielitieteen laitos.

1981: Loppuheiton sosiaalinen variaatio Turun puhekielessä. M. K. SuOJANEN (toim.): Kirjoituksia puhekielestä, 59-78. Turun puhekielen projektin julkaisuja 1. Turun yliopiston suomalaisen ja yleisen kielitieteen laitoksen julkaisuja 14. Turun yliopisto, Turku.

SiItonen, Kirsti 1979: Loppuheitto lounaismurteiden luoteisryhmässä - muutoksen ja variaation ongelmia. Pro gradu -tutkielma. Turun yliopiston suomalaisen ja yleisen kielitieteen laitos.

SKS = Suomalaisen Kirjallisuuden Seura.

SKST $=$ Suomalaisen Kirjallisuuden Seuran Toimituksia.

SMS = Suomen murteiden sanakirja I-VIII. Kotimaisten kielten tutkimuskeskuksen julkaisuja 36. Kotimaisten kielten tutkimuskeskus, Helsinki. 1985-2008.

SMSA = Suomen murteiden sanakirjan arkisto, Kotimaisten kielten keskus.

SMSV = Suomen murteiden sanakirjan verkkoversio. Luettu 6.3.2017. http://kaino.kotus.fi/sms/

Suojanen, M. K. 1985: Mitä Turussa puhutaan? Raportti Turun puhekielen tutkimuksesta. Turun yliopiston suomalaisen ja yleisen kielitieteen laitoksen julkaisuja 23. Turun yliopiston offsetpaino, Turku.

Vihonen, SAKARI 1978: Suomen kielen oppikirja 16oo-luvulla. Kieliopillinen ajattelu 16oo-luvun suomen kielen oppikirjoissa. Studia Philologica Jyväskyläensia 11. Jyväskylän yliopisto, Jyväskylä.

Wirk, Kalevi (toim.) 1987: Suomen wanhat kieliopit 3, 1836-1845. Turun yliopisto, Fonetiikka, Turku. Renvall, Gustaf 1840: Finsk Språklära, Enligt den rena Vest-Finska, i Bokspråk vanliga Dialecten. Åbo.

1990: Suomen kielen morfofonologian historia II. Nominien taivutus 1820-1845. Turun yliopisto, Turku.

1998: Tämmöttös. Turun murteen kielioppi ja harjoituskirja. 2. painos. Unipaps, Turku. 2006: Sano se murteella. Minkälaisia suomen murteet ovat ja missä niitä puhutaan? Pilot-kustannus Oy, Tampere.

Virtaranta, PertTi 1957: Länsiyläsatakuntalaisten murteiden äännehistoria II: Vokaalit. SKST 251. SKS, Helsinki. 
HEIDI SALMI: The Turku dialect in Gustaf Renvall's grammar Finsk Språklära, Enligt den rena Vest-Finska, i Bokspråk vanliga Dialecten (1840)

Gustaf Renvall's grammar Finsk Språklära is based on the pure western Finnish dialect, which is spoken in northern Satakunta, and between Hämeenlinna and southern Ostrobothnia. According to Renvall this is the language, which has been in use in the written Finnish language and which is the most cultured form of Finnish language. Instead Turku dialect is considered to be ugly or poor.

The Turku dialect is a southwestern dialect, but the Häme dialects have also had a great deal of influence on it. Its most important features, which Renvall describes as being typical for the Turku dialect, include: apocope, the truncation of unstressed vowels, vowel combinations which become long vowels, the diftong $e i$ which developed from the $i$ in the words stem and an $i$ following it, word-initial two-consonant clusters, some consonant gradations of $k$, the metathesis of $h$ and weak grades in the past tense and the conditional.

These features are usually not only typical for the Turku dialect but are also used in a wider dialectal area. Some of the features are in fact typical for almost all the southwestern or the western dialects. Some of the features are also typical for the Häme dialects.

These features, still found today, were widely in use in old literary Finnish (in the $16^{\text {th }}-19^{\text {th }}$ century), which was most strongly based on the southwestern and especially Turku dialect.

Heidi Salmi

heidi.salmi@utu.fi

Suomen kieli ja suomalais-ugrilainen kielentutkimus 20014 Turun yliopisto 